\title{
Między rozumem a wolą mocy - światopogląd Tomasza Manna w latach pierwszej wojny światowej
}

\begin{abstract}
Kępa Jacek, Między rozumem a "wolą mocy" - światopogląd Tomasza Manna w latach pierwszej wojny światowej [Between reason and the will to power - Thomas Mann's world view during the First World War]. „Przestrzenie Teorii” 24. Poznań 2015, Adam Mickiewicz University Press, pp. 295-325. ISBN 978-83-232-2982-7. ISSN 1644-6763. DOI 10.14746/ pt.2015.24.16.
\end{abstract}

The work entitled "Reflections of an Unpolitical Man", written during World War I, includes an essay against the Western states. Thomas Mann compares democratic countries and the societies created after the French Revolution with the German concept of society and a country based on conservative values. Equality is set against hierarchy, the individual against the community, and a secular perspective against a religious one. Defiance of the West is based on Protestantism. The references to Nietzsche and Schopenhauer, in agreement with Darwin's theory of evolution, are advanced by the West as an argument for the conflict between rationalism and irrationalism. At the end of Thomas Mann's work, this conflict is solved by the "principle of irony", which gives the author the opportunity to reconcile himself with the concept of democracy. This also dominated his future work.

\section{Sprzymierzeńcy i wrogowie}

Wybuch pierwszej wojny światowej obudził w Tomaszu Mannie poczucie patriotyzmu i skłonił do określenia, czym jest niemieckość. Odpowiedzi, której udzielił, nadał tytuł Rozważania człowieka niepolitycznego. Są one atakiem wymierzonym w ustrój demokratyczny i państwa ententy. Przyczyny wojny, zdaniem Manna, leżą głębiej niż konflikt interesów gospodarczych i walka o pozycję mocarstwa światowego. Wynikają ze zderzenia dwóch różnych światopoglądów: zachodniego, w którym dominuje polityka, zbiorowość, wartości materialne, i niemieckiego, w którym najważniejsza jest jednostka i duchowy wymiar jej istnienia. Esej jest starciem postaci tytułowej i literata cywilizacji. Człowiek niepolityczny uosabia wszystko to, co w niemieckości najlepsze, literat cywilizacji - to, co w krajach Zachodu, przede wszystkim Francji i Anglii, najgorsze. Pierwszym jest Tomasz Mann, który na czas wojny porzucił przemawianie przez fikcyjne postacie swoich powieści i postanowił wypowiedzieć się wprost, drugim - starszy o cztery lata brat Henryk, którego imię wprawdzie nie pada, ale cytowane fragmenty jednoznacznie zdradzają jego toż- 
samość. Poglądy człowieka niepolitycznego poznajemy bezpośrednio, poglądy literata cywilizacji - pośrednio, w interpretacji tego pierwszego. Przeciwnicy są pisarzami, dlatego, choć spór dotyczy wojny, polityki i historii, choć porusza zagadnienia filozoficzne, ma swój początek w sferze sztuki. Demokracja podważa jej podstawy i stawia pod znakiem zapytania dalszą twórczość człowieka niepolitycznego. Zanim będzie mógł do niej wrócić, musi przemyśleć od nowa jej założenia, dokonać ponownego samookreślenia. Rozważania na temat sztuki prowadzą do pytań o istotę człowieczeństwa, wymagają określenia postawy politycznej, zmieniają się w dyskusję na temat europejskiej historii ostatnich stuleci, zależności między jednostką i jej interpretacją świata a poglądami epoki. Zdaniem Tomasza Manna człowieczeństwo jest świadomością własnej wyjątkowości. Nowoczesne społeczeństwo zachodnie świadomość tę spłyca, odbiera, zmienia jednostki w masy, które muszą być trzymane w ryzach za pomocą chłodnej, bezosobowej, racjonalnej polityki. Polityka i człowieczeństwo się wykluczają. Aby sprzeczność między nimi wyeliminować, Mann rozciąga własne poczucie wyjątkowości na cały naród i szuka potwierdzenia swoich sądów, odwołując się do irracjonalizmu. Społeczeństwo, polityka, rozum i Zachód literata cywilizacji zderzają się z jednostką, człowieczeństwem, irracjonalizmem i Niemcami człowieka niepolitycznego. Rozważania poświęcone są rozwijaniu i uzasadnianiu tych przeciwieństw.

By utwierdzić się w przekonaniu o słuszności własnej postawy, Tomasz Mann przywołuje poglądy europejskich i niemieckich pisarzy, filozofów, teologów, historyków, teoretyków prawa, kulturoznawców, socjologów, muzyków i polityków, a gdy uznaje je za własne, rezygnuje z ich samodzielnego formułowania i obszernie cytuje. Przeciwstawienie żywiołów germańskiego i romańskiego na przykład w pierwszym rozdziale opiera na sądach Fiodora Dostojewskiego. Inne myśli tego pisarza stanowią trzon rozważań o fundamentach sprawiedliwego społeczeństwa w rozdziale $O$ wierze. Podziw dla Dostojewskiego, przekonanie o wewnętrznym pokrewieństwie literatury rosyjskiej i niemieckiej prowadzi Tomasza Manna w roku 1917 do żądania zawarcia pokoju z Rosją i nadziei na korzystne zakończenie wojny na Zachodzie. Oprócz Dostojewskiego przywoływany jest Lew Tołstoj, Mikołaj Gogol, Iwan Turgieniew i Aleksander Puszkin. Z twórców francuskich pojawia się Romain Rolland, z którym Mann prowadzi dyskusję na temat zachodniego relatywizmu i różnic między kulturą a cywilizacją, Emil Zola, którego twórczością posłużył się Henryk Mann, by przeciwstawić się poglądom brata, Georges Bizet, Paul Claudel, August Rodin, Georges Sorel, Gustave Flaubert, Blaise Pascal, Paul Cézanne i Madame de Staël, pochodząca z francuskojęzycznej części Szwajcarii. Padają nazwiska polityków: François Guizota 
i Aristide Brianda oraz innych pisarzy spoza Niemiec: Geörgy Lukácsa, Henryka Ibsena i Thomasa Carlyle'a.

Jeszcze istotniejszą rolę odgrywają twórcy niemieccy. Największy wpływ na człowieka niepolitycznego miał Arthur Schopenhauer, Fryderyk Nietzsche i Ryszard Wagner. To oni ukształtowali jego rozumienie niemieckości. Stanowią nierozerwalną całość tak dalece, że mówiąc o jednym, mówi o wszystkich. Poznanie ich twórczości uczyniło z Manna pisarza dekadencji, schyłku i napełniło niechęcią do polityki. Za sprawą Schopenhauera stał się konserwatystą, umniejszył rolę rozumu i uznał przemoc za naturalny, nieusuwalny element ludzkiego świata. Wagner to dla niego także przedstawiciel dekadencji, który przeszedł długą drogę od zwolennika rewolucji 1848 roku do monarchisty akceptującego osiągnięcia Bismarcka. Od Nietzschego przejął pojęcie życia i zinterpretował w duchu własnego rozumienia sztuki jako przestrzegania mieszczańskich nakazów etycznych. Był przekonany, że za jego atakami na chrześcijaństwo kryje się wielka wrażliwość moralna, która upodabnia go do Pascala. Nietzsche swoją twórczością sprzeciwiał się wpływom demokracji. Lektura jego dzieł sprawiła, że Mann stał się niechętny Anglii i Francji. Aprobował pogląd filozofa, że wojna jest koniecznym elementem odradzania kultury. Skierowane przeciw Zachodowi stanowisko człowiek niepolityczny dostrzega także w filozofii Immanuela Kanta. Jego syntetycznym sądom a priori każe zwalczać relatywizm poznawczy, imperatyw kategoryczny nazywa wojennym i zwraca go przeciw demokracji, a Krytyke praktycznego rozumu stawia na równi z krytyką moralności Nietzschego.

Tomasz Mann bardzo wysoko cenił twórczość Goethego. Jej istotą był humanistyczny ideał niemieckiego indywidualizmu, w którym poeta widział źródło reformacji. Pierwszy rozdział Rozważań, zatytułowany Protest, przedstawia wojnę jako kontynuację odwiecznego duchowego sprzeciwu wobec politycznej hegemonii Zachodu, wyrażonego właśnie przez reformację, jako jego ostateczny, najpełniejszy wyraz:

Tak więc, moim zdaniem, od pierwszej chwili istniała daleko idąca jednomyślność co do tego, że duchowe korzenie tej wojny, którą mamy wszelkie prawo nazwać „wojną niemiecką”, leżą we wrodzonym i historycznym „protestantyzmie” Niemiec, że ta wojna oznacza w istocie nową eksplozję najwspanialszej może, ostatniej, jak sądzą niektórzy, prastarej niemieckiej walki z duchem Zachodu, walki świata rzymskiego z krnąbrnymi Niemcami ${ }^{1}$.

1 T. Mann, Betrachtungen eines Unpolitischen, Frankfurt am Main 2001, s. 67. Tłumaczenie fragmentów obcojęzycznych, jeśli nie zaznaczono inaczej, pochodzi od autora opracowania. 
Protestantyzm ma ocalić niemiecką kulturę, uniemożliwić w Niemczech rewolucję podobną do francuskiej i zażegnać niebezpieczeństwo pojawienia się demokracji. Potwierdzenia swoich poglądów człowiek niepolityczny szuka również u takich postaci, jak Friedrich Schiller, Theodor Fontane, Hans Pfitzner, Max Weber, Max Scheler, Adam Müller, Emil Hammacher, Wilhelm von Humboldt, Georg Herwegh, Johann Gottlieb Fichte, Heinrich Treitschke, Bogumił Goltz, Georg Wilhelm Friedrich Hegel, Paul de Lagarde, Julius Langbehn, Joseph von Eichendorff, Theodor Mommsen, Christoph Martin Wieland, Heinrich Heine, Jacob Grimm, Johann Ludwig Uhland i Theodor Storm. Conrad Ferdinand Meyer i Gottfried Keller to piszący po niemiecku pisarze szwajcarscy. Z polityków wymieniony jest Otto von Bismarck, Theobald von Bethmann-Hollweg, kanclerz Niemiec w latach pierwszej wojny światowej, wzmiankowani są socjaldemokraci: Philipp Scheidemann, Wolfgang Heine, Eduard David, August Bebel, Wilhelm Liebknecht i Paul Lensch.

Wszyscy twórcy umieszczeni zostają w zachowawczym, konserwatywnym polu oddziaływania reformacji. Wszyscy kontynuują wyrażony nią proces budowania niemieckości skierowanej przeciw Zachodowi. Na sześciuset stronach Rozważań znalazły się cztery tysiące cytatów i odniesień pochodzących od czterystu różnych autorów ${ }^{2}$, których zadaniem jest potwierdzenie niemieckiej odrębności światopoglądowej. Komentarze człowieka niepolitycznego, jego interpretacje nacechowane są dużą dozą subiektywizmu, silnymi emocjami i zmieniają się wraz z nimi, co sprawia, że te same postacie, procesy lub pojęcia w różnych częściach eseju bywają różnie przedstawiane i oceniane. Ta niespójność wynika także z faktu, że Rozważania są trudnym procesem poszukiwania prawdy o sobie samym. Twierdzenia literata cywilizacji początkowo wyzwalają w człowieku niepolitycznym gwałtowny sprzeciw. Gromadzi wokół siebie sprzymierzeńców, by je zwalczać. Dopiero w dalszych partiach eseju miejsce bezwarunkowej negacji zajmuje formułowanie własnego stanowiska.

\section{Sztuka niemiecka kontra francuska literatura}

Zdaniem człowieka niepolitycznego niemiecka sztuka zawdzięcza swoje istnienie i wartości mieszczaństwu, które kształtowało się i umacniało wraz z rozwojem miast i Hanzy, w warunkach zupełnej obojętności na politykę. W przeciwieństwie do innych krajów nie doszło w Niemczech

2 Esej zawiera 2561 cytatów bezpośrednich, reszta to cytaty niezaznaczone i odwołania. Najczęściej, zawsze anonimowo, cytowany jest Henryk Mann, dalej Nietzsche i Dostojewski. Patrz: T. Mann, Betrachtungen eines Unpolitischen, Kommentar von Hermann Kurzke, Frankfurt am Main 2009, t. 13.2, s. 56. 
do przymierza między mieszczaństwem a władcą, dzięki czemu przez kilka stuleci mogło się ono rozwijać tylko kulturowo, bez politycznego dziedzictwa stanu rycerskiego. Średniowiecze sprawiło, że „w sferze niemieckości mieszczańskość i duchowość, mieszczańskość i mistrzostwo artystyczne stały się pojęciami głęboko spokrewnionymi znaczeniowo"3 i w tej formie oddziaływały one na twórczość najważniejszych dla człowieka niepolitycznego pisarzy. Spadkobiercą tak rozumianej tradycji mieszczańskiej czuje się także on sam. I w mieszczańskim stylu życia, i w mieszczańskiej sztuce pierwszorzędne znaczenie mają etyczne nakazy systematyczności, obowiązkowości, porządku, trwałości i niezależności od nastroju chwili. Pisarstwo jest dla Tomasza Manna ściśle związane z przestrzeganiem zasad moralnych. Sztuka, przeniknięta etyką czerpiącą z wiary, owocuje silnie rozwiniętym życiem wewnętrznym i wysoką samoświadomością, z których rodzi się poczucie społecznej wspólnoty. Niemiecka sztuka mieszczańska nie służyła przedstawianiu piękna, lecz kształtowała etyczną postawę wobec życia, której częścią było powszechne dążenie do politycznej jedności. Twórczość pierwszych dziesięcioleci XIX wieku przygotowała zjednoczenie Niemiec. Dokonywało się ono wbrew zachodniej nowoczesności, zdominowanej przez masy, politykę i rozum. Pragnąca ocalenia przeszłości sztuka musi więc podkreślać wyjątkowość jednostki, arystokratyczne człowieczeństwo i dopełniający je irracjonalizm, którego wyparło się oświecenie:

[Sztuka] zawsze będzie „nakierowana wstecz”, reakcyjna. Nie na darmo zalicza się ją, podobnie jak religię, do potęg antyintelektualnych, a utożsamianie artysty z „intelektualistą" jest demokratyczną blagą. Sztuka nigdy nie będzie moralna w sensie politycznym, nie będzie niewinna. Postęp nigdy nie będzie mógł na nią liczyć. Jest zawodna, ma fundamentalną skłonność do zdrady. Jej zachwyt skandalicznym antyrozumem, jej sympatia dla stwarzającego piękno „barbarzyństwa” są nieusuwalne, [...] [Sztuka to] Wielka, irracjonalna siła ${ }^{4}$.

Artysta sięga do najgłębszych pokładów ludzkiej natury, dzięki czemu potrafi odczytać wolę narodu:

Sądzę, że nie byłby dobrym artystą ten, dla którego to, co prymitywne, byłoby całkowicie obce, który nie byłby zdolny „powrócié” do prymitywizmu. Artysta, twórca jest nim być może tylko o tyle, o ile prymitywizm nie jest mu obcy, a nawet zakładając, że byłby „mieszczaninem”, jest artystą i twórcą być może tylko o tyle, o ile sam jest częścią narodu i nie zapomniał, co znaczy patrzeć i odczuwać na sposób prymitywnie ludowy ${ }^{5}$.

3 T. Mann, Betrachtungen eines Unpolitischen, Kommentar von Hermann Kurzke, Frankfurt am Main 2001, s. 132.

${ }^{4}$ Tamże, s. 405.

5 Tamże, s. 168. 
Dopiero uwzględnienie pierwotnego, mitycznego, irracjonalnego, barbarzyńskiego elementu niemieckości czyni z osoby artystę, a z wielu osób przemawiający jednym głosem naród, którego wolę artysta wyraża, nie potrzebując do tego urn wyborczych.

Sztuka jest drugim, obok religii, reformacji, sposobem jednoczenia Niemców w ich światopoglądowym sporze z Zachodem:

Sztuka jako rozbrzmiewająca etyka, jako fuga i kontrapunkt, jako radosna i poważna pobożność, jako gmach świętości, w którym wszystko się przenika, połączone sensownie i rozumnie, bez murarskiej zaprawy, trzymane „ręką Boga” - ta l'art pour l'art naprawdę jest moim ideałem sztuki, którego w żadnym wypadku nie przedstawiam, ale do którego w moich dążeniach zawsze będę się zbliżał ${ }^{6}$.

Jej najdoskonalszym spełnieniem jest muzyka, która od czterech stuleci towarzyszy protestantyzmowi:

Wychowanie Niemców ku muzyce rozpoczęło się z Marcinem Lutrem, pedagogiem o wyzywająco narodowym obliczu, teozofem, nauczycielem religii i muzykiem w jednej osobie, i to tak bardzo, że muzykalność i religijność były dla niego nie do odróżnienia, że w jego duszy jedno stawało się drugim i od tamtej pory pozostaje istotą niemieckości ${ }^{7}$.

Razem z filozofią, religią i mistyką muzyka chroni Niemców przed zgubnym wpływem oświecenia i nauk przyrodniczych. Racjonalizm, który reprezentowany jest przez psychologię, uwalniając od przesądów, odbiera wyobraźnię, tłumi spontaniczność, ogranicza indywidualne wybory, niszcząc opierającą się na różnorodności sztukę. Rozum zagraża sztuce, ponieważ dąży do usunięcia obecnego w niej prymitywizmu i do panowania nad namiętnościami. Jest ona wyrazem witalności człowieka pierwotnego, jego instynktów i odruchów, które współczesna cywilizacja chce kontrolować, pozbawiając go naturalnego bogactwa, sprowadzając do bezwolnego narzędzia postępu technicznego. Nowoczesność wtłacza ludzkość w gorset zakazów i nakazów, które zastąpią indywidualną moralność i zabiją $w$ jednostkach głębię duchowego życia, ich samoświadomość i wyjątkowość. Ograniczenie człowieczeństwa do rozumu czyni z człowieka płaską, jednowymiarową istotę pozbawioną kontaktu z samą sobą, wegetującą $\mathrm{w}$ społeczności istot sobie podobnych, nieświadomych, czym naprawdę jest życie. Wiedzę tę utracili już artyści zachodni.

Nawiedzona nieszczęściem Francja [...] szybkimi krokami i niepowstrzymanie zmierza do upadku, cała Francja, a szczególnie jej sztuka. Dlaczego? Z powodu wolności. [...] „Wiek XIX dał artystom wolność i tym ich zrujnował. Jakby wol-

${ }^{6}$ Tamże, s. 330-331.

7 Tamże, s. 331. 
ność mogła inspirować sztukę! Ona sztukę zabija! Z wolnością umarły wspaniałe [architektoniczne] style przeszłości, pozostało nam tylko ich nieudolne naśladowanie. Wraz z rewolucja sztuka stała się kramarzem i z powodu tej zmiany umarła"s.

Zachód buduje cywilizację coraz doskonalszą technicznie, ale coraz uboższą duchowo, dlatego prawdziwa sztuka, sztuka niemiecka, musi zwrócić się przeciw nowoczesności:

Pozwólmy spełnić się utopii postępu, uzdrowieniu ziemi przez rozum - temu marzeniu społecznego eudajmonizmu, pozwólmy urzeczywistnić się ziemi esperanta: statki powietrzne krążą nad ubraną na biało, bogobojnie rozsądną „ludzkością”, zjednoczoną z pominięciem państwowości, mówiącą jednym językiem, technicznie w najwyższym stopniu niezależną, komunikującą się na odległość dzięki elektryczności. Sztuka będzie nadal istnieć, będzie stanowić element niepewności, przechowywać dającą się pomyśleć możliwość zwrotu ku przeszłości. Będzie mówić o namiętnościach i nierozsądku, namiętności i nierozsądek przedstawiać, kultywować i sławić, otaczać szacunkiem pierwotne myśli, pierwotne instynkty, ożywiać je i z wielką siłą nieustannie pobudzać, myśl i instynkt wojny na przykład... Nie będzie można jej zabronić, ponieważ sprzeciwiałoby się to wolności. A może „ludzkość” będzie żyła w warunkach absolutyzmu, tyranii rozumu, niewinności i szczęścia? W takim razie jest jeszcze bardziej prawdopodobne, że sztuka znajdzie się całkowicie w opozycji i wszystko, co stanie się opozycją przeciw tej ostatniej tyranii, chętnie połączy z nią swe siły. Sztuka stanie na czele stronnictwa dążącego do obalenia rządów niewinności, a potrafi być przywódczynią porywającą. Krótko mówiąc, wojna, reakcyjne bohaterstwo, każdy wybryk nierozsądku na ziemi będzie do pomyślenia, a więc i możliwy, jak długo istnieć będzie sztuka, a istnieć będzie tak długo, jak istnieć będzie „ludzkośćc”.

Tylko sztuka potrafi przeciwstawić się rozumowi, zburzyć oparty na nim sztuczny porządek społeczny i poprzez pośrednie stadium wojny i barbarzyństwa przywrócić naturalność pierwotnego człowieczeństwa. Gdyby dano jej szansę odrodzenia przeszłości, stworzyłaby idealną społeczność niemiecką, która stałaby się wzorem do naśladowania dla całej ludzkości.

Sztuki nie należy mylić z literaturą. Jest odzwierciedleniem niemieckości, literatura natomiast w imię demokracji niemieckość zwalcza. Człowiek niepolityczny rozumie przez literaturę powieść społeczną, naturalistyczną. Dominuje w niej racjonalizm pod postacią retoryki i psychologii, oraz erotyka. W przeciwieństwie do poezji i dramatu nie jest to gatunek niemiecki. Jej skłonność do satyry ukształtowała się we Francji. Dlatego popularność powieści w Niemczech można traktować jako mier-

8 Tamże, s. 521.

9 Tamże, s. 406-407. 
nik demokratyzacji. To ona jest domeną literata cywilizacji - estety, który podziwia sztukę południa Europy, wyznaje dionizyjski kult piękna i odrzuca religię - jedyną więź, która w jednostkach potrafi obudzić poczucie wspólnoty. Służba Bogu przeczy, w jego mniemaniu, godności człowieka. Skoro odrzuca religię, odrzuca także niemieckość:

z własnym narodem nie łączy go żadna myśl, żadne wyobrażenie, żadne uczucie. [...] Niemiecka muzyka nigdy nie poruszyła jego serca, nie zapłodniła ducha, nie rozumie żadnego dźwięku i rozumieć nie chce. Nigdy nie przeżył wzniosłego upojenia niemiecką mistyką, nie sprzyja ona postępowi i dlatego jest niedogodna. Jego stosunek do wybitnej niemieckości to obcość, odrzucenie, głęboka wrogośćc ${ }^{10}$.

Życie własnego narodu wykorzystuje do pisania krytycznych powieści społecznych, podziwia natomiast i kocha Francję, opowiada się po stronie ententy. Nie są dla niego ważne tradycje niemieckiego mieszczaństwa, lecz polityka jako narzędzie osiągania praktycznych celów, nie przeszłość, którą odrzuca, lecz przyszłość narodu niemieckiego. Państwo nie jest widzialną formą rzeczywistości idealnej, strażnikiem przekonań religijnych wspólnoty, nie ma niezależnego fundamentu duchowego, który stanowiłby rdzeń narodowej tożsamości. Jest powołaną na podstawie umowy społecznej organizacją służącą wygodzie ludzi i zaspokajaniu ich doczesnych, materialnych potrzeb. Literat cywilizacji reprezentuje poglądy francuskiej burżuazji. Duchem należy do czasów rewolucji francuskiej i chciałby jej rozwiązania przenieść na grunt niemiecki. Uważa, że władzę w Niemczech sprawuje armia i junkrzy. To oni ponoszą odpowiedzialność za wybuch wojny i powinni zostać za to ukarani. Ponieważ rządzący nie reprezentują woli narodu, można ich uznać za władzę obcą i dążyć do jej obalenia. Jest przekonany o moralnej wyższości demokracji, choć nie można go uznać za socjaldemokratę, bo partia socjaldemokratyczna ostatecznie poparła wojenny wysiłek Niemiec ${ }^{11}$. Przyspiesza klęskę swej ojczyzny, negując dorobek Lutra, Goethego, Bismarcka i Nietzschego. Oczekuje klęski Niemiec jako zadośćuczynienia za nieudaną rewolucję 1848 roku, niepowodzenie idei zjednoczenia Niemiec przez siły demokratyczne i klęskę Francji w roku 1870, dzięki której zjednoczenie mogło się dokonać. Jest niemal Francuzem, francuskim patriotą, wierzącym w misję narodu, który został przeznaczony na nauczyciela ludzkości.

Słownik rewolucji burżuazyjnej jest jego słownikiem. [...] Człowiek, prawa człowieka, wolność, równość, rozum, naród, tyrani. Posługuje się tymi pojęciami z tą samą zdumiewającą swobodą, co jakobini, i podobnie jak oni tworzy z nich do-

10 Tamże, s. 556.

11 Chodzi o wyrażaną kilkakrotnie zgodę Reichstagu, w tym także socjaldemokratów, na zaciągnięcie kredytów wojennych. 
gmat, którego radykalizm dla umysłu kierującego się sumieniem jest przerażająco płytki. [...] Ma jakobińską skłonność do anarchii $i$ despotyzmu, sentymentalizmu $i$ doktrynerstwa, terroryzmu, fanatyzmu, do radykalnych dogmatów, do gilotyny. [...] Na własną rękę wypracował sobie, znany od dawna, światopogląd duchowo-polityczny, określany mianem kosmopolityczno-radykalnego, demokratycznego internacjonalizmu. Ponieważ jednak ten słynny kosmopolityczny radykalizm rozważał w samotności, samodzielnie i prawie bez lektur, wydaje mu się on tak wyjątkowy i porywająco prawdziwy, tak bardzo jawi mu się jako Prawda i Światło, że każdego, kto uchyla się od jego uznania lub tylko ociąga, uważa za idiotę i szubrawca ${ }^{12}$.

Literat cywilizacji tak bardzo nienawidzi Niemiec, że dla ich pokonania nie cofnąłby się przed rewolucyjnym rozlewem krwi. Patriotyzm rozumie jako dążenie do obalenia monarchii i wprowadzenia demokracji na wzór zachodni:

Nie przeczuwaliśmy, że pod pozorem pokojowych stosunków międzynarodowych w dalekim Bożym świecie nienawiść, nieusuwalna, śmiertelna nienawiść politycznej demokracji, wolnomularsko-republikańskiego retora burżuazji z roku 1789 przygotowywała swe przeklęte dzieło skierowane przeciw nam, przeciw ustrojowi naszego państwa, naszemu duchowemu militaryzmowi, duchowi porządku, autorytetu i obowiązku... ${ }^{13}$.

Jego celem jest całkowita zmiana charakteru narodowego:

Niemcy jako republika, jako państwo cnoty z umową społeczną, demokratycznym rządem i „zupełną przemianą jednostek w masy”, Niemcy jako państwo i nic więcej, Niemiec jako jakobin i citoyen vertueux ze świadectwem poprawności w kieszeni - to byłoby straszne! To dosłownie nie byłyby już Niemcy ${ }^{14}$.

Jako zwolennik gospodarczego liberalizmu kieruje uwagę ludzi ku sprawom doczesnym i na pierwszym miejscu stawia ekonomię; przemysł i handel. Jest pacyfistą, ale akceptuje wojnę cywilizacji przeciw barbarzyńskim Niemcom. Podziwia francuskie, potępia niemieckie czyny wojenne. Dla realizacji swoich celów byłby gotów uznać Ren za granicę między Francją a Niemcami, jak to już było za czasów Napoleona. Swoją twórczością przyspiesza proces, który pozbawi Niemców ich opartej na religijnym indywidualizmie tożsamości i zmusi do stworzenia społeczeństwa laickiego. Wierzy

w postęp, w ludzkość i jej doskonalenie, w cel rozwoju, którym jest szczęście, w ów „piękny i beztroski” stan, do którego zmierza drogą błyskotliwych osiąg-

\footnotetext{
12 T. Mann, dz. cyt., s. 394-396.

13 Tamże, s. 57.

14 Tamże, s. 292.
} 
nięć, w antymetafizyczne, antyreligijne Państwo Boże. Zamiast w niebie podstępnego kleru powstanie ono w ziemskiej przyszłości, w tym, co ludzkie ${ }^{15}$.

Literatura ma pomagać w realizacji tych zamiarów, „propagować reformy natury społecznej i politycznej" 16 .

I człowiek niepolityczny, i literat cywilizacji w procesach drugiej połowy XIX wieku i wojnie światowej widzą przyczynę zmian, które prowadzą niemieckie społeczeństwo ku nowoczesności. Jedna i ta sama wizja społeczeństwa masowego, opartego na osiągnięciach rozumu i rozwoju techniki, wywołuje zupełnie odmienne reakcje. Literat cywilizacji jest przepełniony wiarą $\mathrm{w}$ zachodnie społeczeństwo, które dzięki nauce, postępowi osiągnie na ziemi szczęście, błędnie poszukiwane do tej pory $\mathrm{w}$ niebie, i przybliża tę chwilę swymi krytycznymi powieściami. Sztuka jest, jego zdaniem, sprzymierzeńcem przyszłości, angażuje się w jej urzeczywistnianie racjonalnymi, zaangażowanymi formami wyrazu artystycznego. Człowiek niepolityczny natomiast skupienie na zewnętrznych aspektach tworzenia społeczności doskonałej uważa za lekceważenie człowieczeństwa, dostrzega niebezpieczeństwo przemiany ludzkości w jednolitą, pozbawioną podmiotowości, posłuszną odgórnym nakazom masę, podporządkowaną dyktatowi rozumu nauk ścisłych, zniewalającej sile nowoczesnych wynalazków i rozleniwiającemu dobrobytowi. Sztukę wykorzystuje do ocalenia wyrugowanych przez rozum wartości, które posłużą kiedyś stworzeniu lepszego, pełniejszego, harmonijnego, niemieckiego świata. Poglądy radykalnego literata są dla człowieka niepolitycznego tak oburzające, że gdyby do nich miało należeć ich ostateczne zwycięstwo, nie potrafiłby dalej żyć. Zagrożony $\mathrm{w}$ indywidualnym i narodowym istnieniu, rozwija własną koncepcję niemieckości.

\section{Rozważania człowieka niepolitycznego}

Na podstawie odwołań do sfery nadprzyrodzonej, do której sięga, posługując się religią i sztuką, Tomasz Mann tworzy konserwatywną koncepcję człowieka, narodu i państwa, by wykorzystać ją do walki z Zachodem i demokracją w imię obrony zjednoczonych w roku 1871 Niemiec:

Jestem głęboko przekonany, że naród niemiecki nigdy nie będzie kochał politycznej demokracji z tego prostego powodu, że samej polityki kochać nie potrafi, że okrzyczane „państwo zwierzchnie” dla narodu niemieckiego jest i pozostanie właściwą, przystępną i pożądaną w gruncie rzeczy formą państwowości ${ }^{17}$.

\footnotetext{
15 Tamże, s. 497-498.

16 Tamże, s. 48.

17 Tamże, s. 51.
} 
W nim wyraża się najpełniej właściwa Niemcom hierarchia wartości, w której najwyższe miejsca zajmują Bóg, ojczyzna, cesarz, wolność, miłość, nauka i sztuka. Zasady państwa zwierzchniego powracają do rozwiązań, w których niemieckość wyrażała się już w odległej przeszłości. Niemcy powinni

posłać do diabła zachodni demokratyzm i powrócić do jedynej, uzdrawiającej, starogermańskiej relacji między królem o władzy absolutnej a wolnym narodem, ponieważ w takim królu samo pojęcie wolności zostaje podniesione do najwyższej, wypełnionej boskością świadomości. Naród jest wolny tylko wtedy, gdy rządzi jeden, a nie wielu ${ }^{18}$.

Ludzki egoizm, bezwzględność, niesprawiedliwość, kłamliwość, złośliwość i głupota sprawiają, że

powstaje konieczność skupienia władzy w jednym, stojącym ponad ustawami i nieodpowiadającym nawet przed prawem człowieku, przed którym wszyscy chylą głowy i który traktowany jest jako istota wyższego rzędu, jako władca z woli Bożej. Tylko tak można na dłuższą metę zapanować nad ludzkością i nią kierować ${ }^{19}$.

Proponowana przez pisarza koncepcja polityczna to właściwy narodowi niemieckiemu porządek feudalny z książętami i cesarzem, strzegącym pokoju i reprezentującym jedność państwa. Odwołania te odpowiadają potrzebom współczesności:

W naszych przeoranych różnymi ideami i burzliwych czasach musiała pojawić się ponownie idea średniowiecznego uniwersalizmu, którą można nazwać reakcyjną, ale która ma jednak bardzo dużo wspólnego z pragnieniami współczesnej Europy, spoglądającej wstecz, ponad zaklętą granicę XVI stulecia! ${ }^{20}$.

Panowanie jednego nad wieloma charakteryzuje całą przyrodę, od pszczół i mrówek po wilki i słonie, monarchiczną organizację ma nawet Układ Słoneczny. Jest ona także właściwa ludziom. Dlatego średniowieczne rozwiązania polityczne umożliwiały jednostce ścisły kontakt z naturą:

„Zasada feudalna”, każdy rodzaj konserwatyzmu; religijny, monarchiczny, narodowy, obyczajowy, gospodarczy, każdy sprzeciw wobec zwyrodnienia i rozkładu, spowodowanego postępem, jest zakorzeniony w ziemi i jest naturalnym przeciw-

18 Tamże, s. 138.

19 Tamże, s. 143 (Mann cytuje słowa Schopenhauera).

20 Tamże, s. 136. 
nikiem innej zasady, demokratycznej, zasady praw człowieka, która nie jest zakorzeniona nigdzie poza „rozumem”21.

Francja i państwa Zachodu dążą do zjednoczenia całej ludzkości w jednym, światowym mocarstwie, postępując śladami starożytnego Rzymu, którego spadkobiercami się czują. Wcześniej dziedzicem Rzymu było chrześcijaństwo, które polityczne zjednoczenie ludzkości zastąpiło zjednoczeniem religijnym i przez całe średniowiecze głosiło ideę opartej na wierze w jednego Boga monarchii uniwersalnej, ale dążąc do jej realizacji, wyrzekło się swej duchowej istoty i stało się niewolnikiem polityki, torując drogę rewolucji francuskiej i jej najskrajniejszej odmianie - socjalizmowi. Armie ententy, tocząc na frontach pierwszej wojny światowej krwawe boje z armią niemiecką, chciały uczynić z Niemiec część światowego imperium demokracji. Odebrano by im w ten sposób duchowy, metafizyczny fundament, na którym zbudowana została świadomość zarówno narodowa, jak i państwowa. Zawierająca w sobie piękno prawdziwego człowieczeństwa i wyrażona w postawie człowieka klęczącego potrzeba pełnej szacunku więzi z Bogiem jest jednocześnie wyrazem wolności, jaką dać może tylko wiara i Kościół. Oparcie w wierzeniach religijnych przekazywanych dzięki niemieckiemu kształceniu sprawia, że wspólnota Niemców składa się ze świadomych swej wyjątkowości jednostek, z których każda jest geniuszem i światem samym w sobie:

„Podczas gdy u narodów romańskich i słowiańskich tylko masy charakteryzują się określonymi cechami i tylko „masy” czują się narodem, Niemiec jako jednostka objawia właściwe sobie oblicze duchowe, bojaźń Bożą i naturę, w której rozgrywa się historia świata i w którą się wciela. Dzięki tuzinowi Francuzów, Rosjan, Polaków czy Włochów łatwiej zrozumieć te cztery narody, niż pojąć naród niemiecki po przestudiowaniu tysięcy Niemców. Niemiec [...] porównany z przedstawicielami innych narodów jest osobowością, geniuszem, kimś o wyjątkowym usposobieniu, ponieważ nie jest figurantem, społecznym czy politycznym zwierzęciem na podobieństwo Francuzów, którzy jeśli dostrzec w nich nie naród, lecz osoby, demaskują się natychmiast jako indywidua pozbawione charakteru i osobowości. Niemiecka nacja nie może mieć charakteru podobnego do innych nacji, ponieważ dzięki literaturze i racjonalizmowi powstała i przeistoczyła się w naród, którego przedstawicieli cała ludzkość zaczyna uznawać za swych nauczycieli i wychowawców. Tak, jesteśmy, byliśmy i będziemy mistrzami; filozofami, teozofami i nauczycielami religii dla Europy i całego świata. To jest nasz geniusz, doskonałość naszej narodowej jedności, godność i misja, której nie wolno nam zamienić na rzecz lub fantom, nazywany przez Francuzów czy Anglików nacją. Jesteśmy i pozostaniemy wyróżnionym narodem światowego mieszczaństwa, światowej historii i właśnie $\mathrm{z}$ tego powodu nie możemy być głupawo dumnym,

21 Tamże, s. 441-442.

\begin{tabular}{l|l} 
Jacek Kępa & $\mathbf{3 0 6}$
\end{tabular} 
podobnym do kłębiącej się zwierzęcej zgrai narodem, przypominającym dzikie gęsi lecace w szyku łacińskiego wielkiego A, który, podobny Francuzom lub Polakom, na każdym zebraniu przeprowadza próbne rewolucje lub wyraża się $w$ jednodniowych republikach ${ }^{22}$.

Zadaniem państwa jest ochrona duchowej tradycji narodu i zapewnienie jej trwania w przyszłości, bo przecież

Także naród jest tworem nie tylko społecznym, ale także metafizycznym. Nie „ludzkość" pojmowana jako suma jednostek, lecz naród jest reprezentantem tego, co powszechne. [...] Mamy więc różnicę między masami a narodem, która odpowiada różnicy między jednostką a osobowością, cywilizacją a kulturą, istnieniem społecznym a metafizycznym. Składające się z jednostek masy są demokratyczne, naród jest arystokratyczny ${ }^{23}$.

Taka właśnie jest mentalność Niemców, dla których przeżycia wewnętrzne są pierwotne wobec doświadczeń społecznych. Przedmiotem ich zainteresowania jest indywidualna relacja ze światem, a nie rola społeczna, jaką w nim odgrywają. Naprawa całego społeczeństwa dokonuje się wyłącznie przez wewnętrzne samodoskonalenie, opierające się na religijności, bez której nie ma mowy o osiągnięciu zgody społecznej. Dlatego

wiary w Boga ludzkość potrzebuje bardziej niż wiary w demokrację. Bo pytanie, czy jednostka może być dobra bez Boga, pozostaje nierozstrzygnięta, ale że masy bez wiary w Boga, bez religii nigdy nie znajdą najmniejszego powodu, by być dobre, to jest absolutnie pewne ${ }^{24}$.

U początków narodu „leżą przekonania transcendentne, które zawsze i wszędzie stawały się wyznaniem wiary, a gdy tylko powstała nowa religia, kształtowała się natychmiast nowa państwowość i narodowość"25. Religia jest środkiem, scalającym zalążki przyszłego organizmu politycznego, który zapewni wierzeniom maksymalną ochronę i jak największy zasięg:

Mamy tutaj w słowach najbardziej klarownych, najprostszych i głęboko poruszających nie tylko etyczną doskonałość jednostki, jej zasady osobiste jako to, co najważniejsze, poprzedzające ideę społeczności, lecz także powstanie narodowości z elementu religijnego, ideę narodu jako religię. Wojnę narodową, w której samookreślenie i rozprzestrzenianie utożsamiają się z sobą tak, że są nie do odróżnienia, rozumiemy jako wojnę religijną ${ }^{26}$.

22 Tamże, s. 257-258. Mann cytuje słowa Bogumiła Goltza (1801-1870), niemieckiego pisarza i pedagoga.

${ }^{23}$ Tamże, s. 262-263.

24 Tamże, s. 539.

25 Tamże, s. 530.

26 Tamże, s. 530. 
Religia służy umacnianiu struktur narodowych i usprawiedliwianiu przemocy. Podobnie jak sztuka, ma swoje korzenie w instynktach człowieka pierwotnego. Także w niej dominuje element irracjonalny, który sprawia, że wojna zostaje wyniesiona na wyżyny człowieczeństwa jako narzędzie szerzenia prawdy i warunek wszelkiego rozwoju. Oznacza uszlachetnienie, spotęgowanie uczuć religijnych i uwolnienie od trosk materialnych. Staje się źródłem mistycznych przeżyć. Trwanie w okopach potęguje świadomość życia, obdarza poczuciem ekstatycznej wolności i pewności, że jest się w rękach Boga. Jest jednym z najgłębszych przejawów humanizmu. Dopiero wojna „stwarza przestrzeń, i to najbardziej rozległą, dla rozwoju miłości”27. Człowiek niepolityczny uważa, że każdy może „uświadomić sobie w przybliżeniu, jakiego duchowego, umysłowego, religijnego wyniesienia, pogłębienia i uszlachetnienia dokonuje w człowieku wieloletnia, codzienna obecność śmierci”28. Aby połączyć wojnę $\mathrm{z}$ religią, pozostaje mu tylko udowodnić, że

To, co humanitarne, nie zawsze i nie wszędzie jest tym, co ludzkie - już wcześniej natrafiliśmy na tę prawdę i ciągle na nowo powraca ona w naszej świadomości. Czy jest do pomyślenia humanitaryzm, filozoficzna odpowiedzialność za los ludzkości lub, aby pojęcie to stało się bardziej konkretne, europejskiej ludzkości, która byłaby dość antyhumanitarna, by ją zaakceptować, uznać za konieczną? Nietzsche [...] udowadnia nam, że jest to możliwe. [...] „Coraz lepiej będziemy rozumieli, że wysoce kulturalnej, a przez to osłabionej ludzkości współczesnej Europy potrzebne są wojny, czyli ograniczone w czasie nawroty barbarzyństwa, by $\mathrm{z}$ powodu wysublimowania nie straciła własnej kultury, by nie przestała istnieć” 29 .

Wojna jest uświęconą i godną najwyższego uznania obroną dawnych wartości:

W zasadzie teleologiczną funkcję wojny określić można ogólnie jako ochronę, utrzymanie i wzmocnienie cech narodowych. Wojna jest potężnym narzędziem zapobiegania rozpadowi kultury narodowej, spowodowanemu racjonalizmem, a mój udział w niej nie ma nic wspólnego z panowaniem nad światem i dominacją gospodarczą, lecz jest niczym innym, jak udziałem w żarliwym procesie samopoznania, samookreślenia i samoutwierdzenia, do czego kulturę niemiecką zmusił olbrzymi napór duchowy, zewnętrzna agresja... ${ }^{30}$.

W imię wyższego dobra człowiek niepolityczny odmawia poparcia pacyfizmowi i umniejsza okrucieństwa zmagań zbrojnych:

\footnotetext{
27 Tamże, s. 467.

28 Tamże, s. 467.

29 Tamże, s. 463.

30 Tamże, s. 134.
} 
Gdybym znalazł się na polu walki i na własne oczy zobaczył ogrom zniszczeń, gdybym musiał patrzeć na obłąkańcze rozszarpywanie ludzkich ciał i słuchać młokosów, którzy wybłagali pozwolenie na ochotniczy zaciąg, a teraz w huraganowym ogniu wroga zawodzą dławionym od płaczu głosem dziecka i wołają „mamo, mamo!”, czy umiałbym pozostać w podniosłym, patriotycznym nastroju? Czy byłbym zdolny do zakrawającego na grubiaństwo napisania dziennikarsko użytecznego reportażu dla „mojego pisma”? Gdyby wojna oddziaływała na mnie jako bezpośrednia rzeczywistość, czyż nie pozostawałbym jednak mimo wszystko trochę nieufny wobec ruiny, jaką napełniłaby moje serce bezgraniczna litość i strach przed własną śmiercią? Czyż nie uświadomiłbym sobie, że liczone w dziesiątkach tysięcy pomnażanie śmierci tak naprawdę nie opuszcza granic jednostkowej indywidualności, że każdy umiera śmiercią własną, a nie innych? Śmierć nie staje się straszniejsza przez to, że widzimy ją zwielokrotnioną. „Człowieczeństwo" nie zapobiega temu, że wszyscy na gorycz śmierci jesteśmy skazani. Śmierć w łóżku bywa równie odrażająca, jak śmierć na polu walki. Każde serce jest zdolne do przyjęcia ograniczonej porcji grozy, później popada się albo $\mathrm{w}$ tępotę, albo w ekstazę, albo osiąga się jeszcze inny stan, niedostępny pojęciu ludzi niedoświadczonych, mianowicie wolność, religijną wolność i radość, wyzwolenie $\mathrm{z}$ więzów życia, więzów strachu i nadziei, co z całą pewnością jest przeciwieństwem duchowego poniżenia i pokonaniem samej śmierci ${ }^{31}$.

By spełnić swe pozytywne cele, wojna wymaga ofiar, dlatego Mann akceptuje złamanie neutralności Belgii, zatopienie Lusitanii i nieograniczoną wojnę podwodną.

Budowana na irracjonalnych elementach ludzkiej natury, odwołująca się do pierwotnego związku człowieka z ziemią, traktująca przemoc jako przejaw świętości i źródło sił twórczych wspólnota społeczna, zorganizowana według naśladujących przyrodę zasad monarchii średniowiecznej, zostaje przeciwstawiona zachodniej demokracji. Tomasz Mann widzi w niej rezultat oświeceniowego fermentu intelektualnego:

Jeśli w poniższych rozważaniach jest broniona lub uważana za oczywistą tożsamość pojęć „polityki” i „demokracji”, dzieje się tak na podstawie niesłychanie łatwo zrozumiałego uzasadnienia. Nie można być politykiem „demokratycznym” lub „konserwatywnym”. „Politykiem” albo się jest, albo nie jest. A jeśli się nim jest, jest się zarazem demokratą. Myślenie o polityce jest myśleniem demokratycznym. Wiara w politykę jest wiarą w demokrację, w umowę społeczną. Wszystko, co od ponad stu pięćdziesięciu lat rozumie się pod pojęciem polityki, wywodzi się z ducha przekonań Jana Jakuba Rousseau. To on jest ojcem demokracji, samego politycznego sposobu myślenia, ojcem człowieka politycznego ${ }^{32}$.

31 Tamże, s. 465.

32 Tamże, s. 50. 
Polityka uczy zazdrości, impertynencji, prostactwa i chciwości, neguje religię i sztukę, dlatego jest antyniemiecka. Państwa zachodnie zmierzają do narzucenia Niemcom obcego im poglądu na świat.

Chodzi o upolitycznienie, zliteratyzowanie, zintelekualizowanie, zradykalizowanie Niemiec, o ich „uczłowieczenie”, w sensie łacińsko-politycznym i dehumanizację w niemieckim... Chodzi, że użyję ulubionego określenia literata cywilizacji, jego triumfalnego okrzyku wojennego, o demokratyzacje Niemiec lub też, streszczając wszystko i sprowadzając do wspólnego mianownika, o ich odniemczenie.... ${ }^{33}$.

Demokracja jest ucieczką przed pustką duchową i formą ochrony interesów materialnych, która żywy organizm społeczny zmienia we wtórną cywilizację. Jest określeniem powszechnej, ogłupiającej pogoni za bogactwami i władzą. Drapieżna polityka zagarniania światowych bogactw ma swoje korzenie w angielsko-francuskim rozumieniu demokracji jako sposobu robienia interesów, przesłoniętych szlachetnymi deklaracjami humanizmu i postępu. Ideami XVIII stulecia Anglicy zarazili najpierw Francuzów, czyniąc ich swymi pierwszymi ofiarami, a następnie całą Europę, wywołując jej kryzys. Za sloganami na temat wolności, równości, braterstwa i poszanowania praw mniejszych państw kryje się rozszerzanie stref wpływów, umacnianie własnej gospodarki i dążenie do światowej hegemonii. Szczytne ideały służą tylko usprawiedliwieniu kolejnych imperialistycznych podbojów. Tomasz Mann wypomina Włochom napaść na Libię, Francji zajęcie Maroka, a Stanom Zjednoczonym wojnę z Hiszpanią. Najwięcej słów krytyki kieruje pod adresem Anglików za bezwzględne postępowanie wobec Hindusów, wojny burskie, wojnę opiumową i okrutne potraktowanie Irlandii. Anglia rozpętała wojnę w obronie małych państw, a przy okazji umacniała swoją dominację, niszczyła niemiecki handel i chciała złamać Niemcy blokadą gospodarczą - „oto demokracja, na tym polega upolitycznienie i na takim wychowaniu własnego narodu polega misja literata cywilizacji”34. Dążący do zjednoczenia Niemcy pozwolili, by materializm zatriumfował także u nich. Proces przemiany kierującego się wartościami duchowymi mieszczaństwa w warstwę żądnej władzy bezwzględnej kapitalistycznej burżuazji dokonał się w drugiej połowie XIX wieku:

około roku 1860 polityka siły Bismarcka i „niemiecka myśl zjednoczeniowa” zbliżyły się w stopniu godnym uwagi. [...] Niemcy [...] przeszły wówczas z okresu idealistycznego do realistycznego, [...] poezja i filozofia zostały zdetronizowane,

33 Tamże, s. 87.

34 Tamże, s. 369. 
największego znaczenia nabrały nauki przyrodnicze i historia, wszyscy zwrócili się ku sprawie utworzenia państwa niemieckiego ${ }^{35}$.

Zupełnie inny wydźwięk miały dążenia niepodległościowe pierwszej połowy XIX wieku. Nie dominował w nich przyziemny materializm, lecz autentyczny niemiecki demokratyzm, który nie poddawał się wpływom Zachodu. Opóźnione zjednoczenie i wkroczenie Niemiec do polityki europejskiej, choć zgodne z dziejowym posłannictwem, oznaczało jednak zwycięstwo ekonomii, degradację życia duchowego, zamianę pozbawionej państwowości kultury na pozbawioną kultury państwowość. W ustroju demokratycznym nie liczą się kompetencje i doświadczenie. „Kto tylko będzie miał chęć i dwa dobre łokcie, prędzej czy później dopcha się do państwowego koryta - wiedza nie będzie potrzebna"36. Demokracja jest panowaniem przeciętności. Zdaniem człowieka niepolitycznego „przytłaczająca większość ludzi pod pojęciem «szczęścia» rozumie obżarstwo i opilstwo lub też, by wyrazić się oględniej i bardziej naukowo, «konsumpcję jak największej ilości dóbr materialnych»"37. Masy „żądają coraz więcej, stają się coraz bardziej niezadowolone, głupsze i niereligijne" 38 . Dlatego harmonia między wewnętrznym bogactwem wychowanych w szacunku dla przeszłości Niemców a ograniczonym do zaspokajania potrzeb konsumpcyjnych społeczeństwem zachodnim nigdy nie zostanie osiągnięta. Rezultatem zwycięstwa ententy będzie Europa trywialna, zepsuta, rozkrzyczana, Europa interesów, płytkich przyjemności i rozrywek, przypominająca paryską kokotę: „na dłuższą metę zasad oświecenia nie da się pogodzić z żadną formą państwowości, ich logiczną konsekwencją jest zniszczenie wszelkich uwarunkowań życia kulturalnego" ${ }^{39}$. Innymi słowy, „demokracja jest formą upadku państwa"40.

Fundamentalne przeciwieństwo między niepolitycznością Niemiec a politycznością Zachodu rysuje się wyraźnie w interpretacji pojęć kultura i cywilizacja. Kultura to siły pierwotne i irracjonalizm, źródło jednostkowej, narodowej i państwowej tożsamości, sięgające mitycznych początków chaosu i przemocy. Z nich wywodzi się także religia i sztuka. W imię obrony tego dziedzictwa Niemcy toczą wojnę z Zachodem, chcąc zapobiec nieszczęściu, jakim może stać się dla ludzkości rewolucja francuska i stworzona przez nią cywilizacja oświeceniowego racjonalizmu. Odbiera ona człowiekowi życiodajną dzikość, pierwotne mity demaskuje jako

\footnotetext{
35 Tamże, s. 251.

36 Tamże, s. 313.

37 Tamże, s. 337.

38 Tamże, s. 337.

39 Tamże, s. 338.

40 Tamże, s. 320.
} 
przesądy, ogranicza pełnię człowieczeństwa, tłumiąc instynkty i namiętności, każe odwracać wzrok od rzeczy ostatecznych, a sens życia sprowadza do pomnażania dóbr materialnych. Różnice między Niemcami a Zachodem określa seria przeciwieństw: wola - rozum, prymitywizm intelektualizm, wojna - pokój, religijność - ateizm, kultura - cywilizacja, duch - polityka, monarchia - demokracja, nauki humanistyczne - nauki przyrodnicze, filozofia - technika, mit - historia, średniowiecze i romantyzm - oświecenie, naród - masy, mieszczaństwo - burżuazja, jednostka - społeczeństwo, sztuka - literatura, etyka - estetyka, ideały duchowe - pieniądze, oczyszczające cierpienie - płytkie szczęście, różnorodność jednakowość, hierarchia - równość, Państwo Boże - umowa społeczna, Marcin Luter - Jan Jakub Rousseau. Wszystkie przeciwieństwa służą odrzuceniu zachodniej współczesności, są próbą ustanowienia konkurencyjnego, niemieckiego systemu wartości i zalążkiem niemieckiej przyszłości Europy, opartej na potędze Prus. Dopiero pojawienie się przywódcy tak charyzmatycznego jak Fryderyk II przywróci Niemcom należne im miejsce. Człowiek niepolityczny ignoruje rok 1789, pragnie powrotu Europy sprzed rewolucji francuskiej, chce historii bez procesów przemiany dawnych królestw w państwa narodowe i zachowania ustroju feudalnego.

Ale wbrew znaczeniu, jakie przypisuje Bogu w tworzeniu i funkcjonowaniu społeczeństwa, oświadcza, że jest człowiekiem niewierzącym: „Nie mogę powiedzieć, że wierzę w Boga. Sądzę, że długo by trwało, nim bym powiedział, nawet gdybym wierzył" 41 . Gwarantem niemieckości jest Bóg, który nie istnieje. To fundamentalna sprzeczność poglądów człowieka niepolitycznego. Powołuje się na Boga nie po to, by dać wyraz swej wierze, lecz by trzymać w ryzach społeczeństwo, uświęcać niemieckość, wykorzystywać do zwalczania poglądów literata cywilizacji i uzasadniać wojnę z Zachodem. Zastępuje Boga przywódcą o nieograniczonej władzy, a swój religijny sceptycyzm skrywa pod pozorem wytrwałego poszukiwania wiary:

Kiedy mówię: nie polityka, lecz religia, nie oznacza to, że chełpię się religijnością. Daleko mi do tego. Nie, nie jestem religijny. Jeśli jednak pod pojęciem religijności mogę rozumieć wolność, która jest drogą, a nie celem, wolność, oznaczająca otwartość, łagodność, akceptację życia, pokorę, poszukiwanie, próbowanie, wątpienie i błędy, a więc, jak mówiłem, drogę, prowadzącą do Boga lub też, wedle mnie, do diabła - tylko, na miłość Boską, precz z tą zatwardziałą pewnością siebie i filisterstwem jedynie słusznej wiary - być może coś z tak rozumianej wolności i religijności mogę nazwać moją własnością ${ }^{42}$.

41 Tamże, s. 538.

42 Tamże, s. 540. 
Absolutny charakter chrześcijaństwa jako drogi prowadzącej do życia wiecznego zastępuje metafizyką użyteczną. Duchowość i wiarę wywodzi nie z objawienia Bożego, lecz z człowieczeństwa wspólnoty pierwotnej. Dla ratowania wiary przed niszczącym wpływem oświeceniowego rozumu uznał ją za siłę irracjonalną i założył, że niemieckość, którą wywiódł z tego samego źródła, będzie jej najlepszym obrońcą. W ten sposób uczynił ze zmagań $\mathrm{z}$ ententą wojnę religijną, a $\mathrm{z}$ religii narzędzie narzucania Europie niemieckiej hegemonii. Irracjonalizm ratuje wiarę, a ona $\mathrm{z}$ kolei uzasadnia współczesne roszczenia polityczne przez odwołania do uniwersalistycznej tradycji średniowiecznej Rzeszy. Ucieczką w irracjonalizm Tomasz Mann nie uduchowił polityki, lecz upolitycznił religię, zaprzeczając tytułowi całego eseju i mnożąc następne sprzeczności. Jednym tchem wymienia pokorę, łagodność i diabła. Literatowi cywilizacji zarzuca aprobatę jakobińskiego terroru, choć dla zwalczania jego poglądów akceptuje wojnę. Miłość wywodzi z masowego cierpienia, a etyczne podstawy kultury mieszczańskiej z pierwotnego barbarzyństwa. Będąc konserwatystą, oświadcza, że jednak nim nie jest. Jeden i ten sam naród jest obdarzanym Bożą mądrością podmiotem metafizycznym, ale potrafi się także zmienić $\mathrm{w}$ pozbawione wyższych uczuć i sumienia masy. Zjednoczenie Niemiec było doniosłym wydarzeniem, które oznacza jednak schyłek kultury. Wierzącego w chrześcijańską odnowę społeczeństw Dostojewskiego zestawia z odrzucającym chrześcijaństwo Nietzschem. W niemieckim filozofie dostrzega i obrońcę kultury, i propagatora demokracji. Bismarck jest wprawdzie drugim Lutrem, ale i on swoją polityką wzmacnia tendencje demokratyczne.

Człowiek niepolityczny dostrzega złożoność sytuacji, konsekwencje kończącej się wojny i konieczność zmian we własnej postawie:

Czymże innym jest ta długa rozmowa z sobą i powstające dzieło, jak nie spojrzeniem na to, czym byłem do tej pory, czym byłem prawdziwie i godnie, i czym, nie czując się staro, widocznie dłużej być nie mogę? Nie ja ostatni uświadamiam sobie znaczenie dokonującej się zmiany, wiem nawet, że starym i na zawsze zamkniętym w przeszłości pozostanie ten, komu nie uda się zawrzeć możliwie dobrej ugody z nowymi czasami. Jeśli chodzi o mnie, muszę zrozumieć, że mam ogarniać nowości, uczyć się, szukać porozumienia, poprawiać siebie. Nie potrafię jednak zmienić mojej istoty, mego wychowania, wyrwać moich korzeni i zapuścić ich gdzie indziej ${ }^{43}$.

W pisanej na samym końcu Przedmowie dopuszcza zarzut, że był złym myślicielem, ponieważ próbował powstrzymać nadejście nowego. By go odeprzeć, stwierdza, że pisarstwo jest „wytworem i wyrazem przeby-

43 Tamże, s. 231. 
wania $\mathrm{w}$ dwóch miejscach naraz, jednoczesnego potwierdzania i negowania, obecności dwóch serc w jednej piersi, wątpliwej obfitości wewnętrznych konfliktów, przeciwieństw i sprzeczności"44. Jeśli nawet stawiał konserwatywny opór nowym czasom, to i tak wspierał je swoim pisarstwem. Ponieważ postęp zawsze przybiera formę walki starego z nowym, jest się po jego stronie także wtedy, gdy się go zwalcza. Od takiego stwierdzenia niedaleko już do deklaracji, że właściwie nigdy demokracji nie zwalczał. Skoro ludzie pragną żyć w jej ograniczeniach, nie należy im $\mathrm{w}$ tym przeszkadzać. Takie przekonanie nosił w sobie od czasu pierwszej lektury dzieł Nietzschego i takie przekonanie podziela obecnie. Już w chwili wybuchu wojny wiedział, że zapowiada ona nadejście demokracji i podzielił się tym sądem $\mathrm{z}$ literatem cywilizacji. Człowiek niepolityczny dostrzega, że zbliżający się koniec wojny powoduje wzrost nastrojów rewolucyjnych, ale nie ma już nic przeciw zmienianiu starego, obarczonego wadami porządku politycznego i jego ewolucji ku demokracji. Ważne tylko, by wymuszone przez współczesność modyfikacje pozwoliły zachować niemieckość. W gruncie rzeczy chodzi o wspólne przedsięwzięcie odnowienia Europy i świata, tyle że podjęte nieodpowiednimi środkami. Przecież Francja i Niemcy miały kiedyś wspólną historię i kulturę. Przeznaczeniem Niemiec nie jest panowanie nad Europą, lecz pobudzanie jej rozwoju. Rozważania człowieka niepolitycznego to tylko reakcja na bezwstydną naukę literata cywilizacji o moralnej wyższości demokracji i obarczaniu Niemiec winą za rozpętanie wojny.

Tomasz Mann dotychczasowych pozycji bronić już nie może, ale bratu wprost racji przyznać nie chce. Uzasadnił już, że swoją zachowawczą postawą wspiera rozwój demokracji. Stwierdza to raz jeszcze, zadając pytanie retoryczne, które oznacza akceptację poglądów brata przy zachowaniu własnej odrębności: „Tak więc moje pisarstwo pozwoliłoby wspierać «postęp» Niemiec we właściwym mi stopniu poprzez jego konserwatywne zwalczanie?"45. Uznaje, że rozwiązanie, dzięki któremu może zaakceptować przemiany polityczne, nie odwołując swych zarzutów, jest zarazem fundamentem sztuki, którego poszukiwanie skłoniło go do napisania Rozważań. Rozwiązanie to nazywa ironią. Widzi w niej istotę konserwatyzmu i szansę na zawarcie rozejmu z demokracją:

Ironia jest formą intelektualizmu, co oznacza, że ironiczny konserwatyzm jest konserwatyzmem intelektualnym. W pewnym stopniu zderza się $\mathrm{w}$ nim byt i działanie. Możliwe, że wspiera on demokrację i postęp przez sposób, w jaki je zwalcza ${ }^{46}$.

\footnotetext{
${ }_{44}^{4}$ Tamże, s. 42.

45 Tamże, s. 61.

${ }_{46}$ Tamże, s. 586.
} 
Pogląd, który człowiekowi niepolitycznemu pozwolił wyjść z twarzą ze sporu z literatem cywilizacji, zostaje uogólniony do postawy światopoglądowej, oznaczającej nieustanny wysiłek pośredniczenia między dwoma wykluczającymi się punktami widzenia, w których spotykają się tendencje destruktywne i zachowawcze. Przeciwstawne racje równoważą się tak idealnie, że nie sposób dokonać wyboru. „Ironia jest nią zawsze na dwie strony, czymś pośrednim, ani jednym, ani drugim, a zarazem i jednym, i drugim"47. Jedyne wyjście to zawieszenie ostatecznej deklaracji i poszukiwanie sposobu przezwyciężenia sprzeczności. Zadaniem sztuki jest zachowanie równowagi między dwoma światami i ich wzajemne zbliżanie.

Jej przesłanie polega na tym, że, mówiąc dyplomatycznie, zachowuje dobre relacje zarówno z życiem, jak i czystym duchem, że jest konserwatywna i radykalna jednocześnie, polega na zachowaniu pośredniego i pośredniczącego stanowiska między duchem a życiem. Oto źródło ironii... Tutaj także, bardziej niż gdzie indziej, widoczne jest pokrewieństwo, podobieństwo między sztuką a polityką. Także ona, na swój sposób, pośredniczy między czystym duchem a życiem. Nie zasługuje na tę nazwę wówczas, gdy jest tylko konserwatywna lub tylko radykalnie destruktywna! ${ }^{48}$.

Artysta nie musi już poszukiwać w sobie prymitywnych instynktów, by wyrazić jedność narodowej wspólnoty, a sztuka nie musi odwoływać się do pierwotnego barbarzyństwa, by chronić kulturę przed cywilizacją. Ramię w ramię z pozbawioną rewolucyjnego radykalizmu polityką szuka kompromisu między religijnym indywidualizmem Niemców a liberalnym społeczeństwem współczesności. Dziejowe znaczenie Niemców nie polega na stosowaniu świętej przemocy usiłującej wskrzesić przeszłość, lecz na poszukiwaniu równowagi między oświeceniowym racjonalizmem a wiarą średniowiecza, by także społeczeństwo przyszłości mogło cieszyć się pełnią człowieczeństwa:

Czyż istotą niemieckości nie jest środek, środkowość i pośredniczenie, a Niemiec człowiekiem środka w wielkim stylu? Jeśli niemieckością jest przynależność do mieszczaństwa, to może jest nią w jeszcze większym stopniu coś pośredniego między mieszczaninem a artystą, patriotą a Europejczykiem, człowiekiem protestu a mieszkańcem Zachodu, konserwatystą a nihilistą [...]? ${ }^{49}$.

Rozwijanie formuły sztuki, polityki i niemieckości jako idei środka położyło kres buntowi Tomasza Manna przeciw poglądom starszego brata, uwolniło od irracjonalizmu, pozwoliło stworzyć własny profil twórczy, stało się posłannictwem, którego spełnieniu poświęcił całą późniejszą aktywność pisarską.

47 Tamże, s. 109.
48 Tamże, s. 574.
49 Tamże, s. 129. 


\section{Historia sporu}

Pierwsze różnice w poglądach braci ujawniły się przy okazji wspólnych pobytów we Włoszech w ostatnich latach XIX wieku i dotyczyły odmiennej oceny włoskiej sztuki. Henryk był nią zachwycony, Tomasz natomiast przedkładał nad nią sztukę niemieckiej, protestanckiej Północy. Dystans wobec twórczości brata i poszukiwanie własnej formy wyrazu artystycznego to dwa oblicza jednego i tego samego procesu, którego etapy prześledzić można zarówno w twórczości, jak i w prywatnej korespondencji ${ }^{50}$. Braci różnił styl i zakres poruszanych treści. Tomasza raziła nieskrępowana erotyka i barokowe bogactwo środków językowych, którymi brat oddawał miłosne uniesienia bohaterów. Powieści Henryka powstawały jedna za drugą, powieści Tomasza pisane były latami. Młodszy brat wybrał styl oszczędny, klasyczny, koncentrował się na przeżyciach wewnętrznych postaci, był przywiązany do mieszczańskiego stylu życia, w przeciwieństwie do żyjącego wśród artystycznej bohemy starszego brata. Nie odpowiadała mu krytyka społeczeństwa niemieckiego zawarta w takich powieściach Henryka Manna jak W krainie pieczonych gotabków, Profesor Unrat czy Poddany. Wszystkie wskazywały na konieczność zerwania z dominującą pozycją cesarza, arystokracji i radykalnej przebudowy systemu politycznego na wzór zachodni. Tymczasem Tomasz uważał, że artysta nie jest powołany do poprawiania rzeczywistości i nie powinien do tego celu wykorzystywać swoich dzieł. Staje się ona lepsza dzięki procesowi samodoskonalenia, który może dokonywać się tylko w warunkach stabilizacji społecznej i bezpieczeństwa, jakie zapewniają konserwatywne Niemcy. W jego poglądach odbija się postawa Lutra, który głosił wewnętrzną wolność jednostki i posłuszeństwo władzom zwierzchnim. Taką postawą różnił się od brata, który uważał, że szczęśliwszym czyni nie wewnętrzna harmonia, lecz zmiana zależnych wyłącznie od człowieka zewnętrznych warunków życia, że nie myślą, lecz czynem, nie indywidualnie, lecz we współpracy z innymi można zmieniać świat na lepszy. Decydująca rozmowa między braćmi, która przerodziła się w kłótnię i zerwanie wszelkich relacji, miała miejsce w drugiej połowie września lub na początku października 1914 roku w mieszkaniu ich wspólnych znajomych ${ }^{51}$. Od tej pory wypowiadali swoje odmienne zdania na łamach różnych czasopism, a ich spór stał się sprawą publiczną.

50 Zob. H. Koopmann, Thomas Mann - Heinrich Mann: Die ungleichen Brüder, München 2005.

51 Wiadomości dotyczące relacji między braćmi zawierają następujące opracowania: P. de Mendelssohn, Der Zauberer. Das Leben des deutschen Schriftstellers Thomas Mann, t. 1-3, Frankfurt am Main 1996; K. Harrprecht, Thomas Mann, eine Biographie, Reinbeck 
W sierpniu i wrześniu 1914 roku Tomasz Mann napisał esej Myśli czasu wojny i opublikował go w listopadowym numerze czasopisma „Neue Rundschau". Esej zawiera idee i sformułowania rozwijane później w Rozważaniach. Sztuka zostaje przedstawiona jako pokrewna wojnie, a kultura przeciwstawiona cywilizacji, tak jak natura przeciwstawia się duchowi. To z niej i wpisanych $\mathrm{w}$ nią pierwotnych instynktów bierze się wartość, siła i trwałość kultury. Obejmuje ona upodobanie do magii, orgii sakralnych, homoseksualizmu i ofiar z ludzi, oznacza inkwizycję, palenie na stosie, procesy czarownic i inne formy zabijania. Cywilizacja natomiast jest wyłącznie rozsądkiem, intelektem, łagodnością, obyczajowością i sceptycyzmem, tłumi namiętności, wypędza demony i jest antyheroiczna. Kultura jako obłaskawiona dzikość, oswojone barbarzyństwo przeciwstawia się cywilizacyjnemu rozumowi. Sztuka, będąc częścią kultury, nie utożsamia się ze współczesnymi, demokratycznymi formami państwa. Towarzyszy wojnie, która odmładza ludzkość, dlatego artysta powinien rozpoznać się w obrazie żołnierza, a wojna jest powodem do radości, ponieważ otwiera przed ludzkością nowe perspektywy, wynosi człowieczeństwo na niespotykane wyżyny, ukazuje prawość i duchowe piękno Niemców, których militaryzm jest niczym innym jak formą moralności. Zachód widzi w Niemczech kraj zacofany cywilizacyjnie, tymczasem system ubezpieczeń społecznych i rozwiązań socjalnych, liczba uniwersytetów, szkół wyższych, niski odsetek analfabetów i przestępców czynią z Niemiec państwo o wiele nowocześniejsze niż Francja czy Anglia. Wrażliwe na sprawy społeczne cesarstwo jest formą polityczną odpowiadającą wyzwaniom przyszłości bardziej niż oparty na rewolucji francuski parlamentaryzm i dlatego właśnie jemu przeznaczone jest ostateczne zwycięstwo, choć anglosascy publicyści i pisarze domagają się przymusowego ucywilizowania, zrzucenia tyranii Hohenzollernów i wymazania całej tradycji pruskiej państwowości ${ }^{52}$.

Tomasz Mann tę właśnie tradycję obdarzał najwyższym uznaniem i przez kilka lat nosił się z myślą o powieści poświęconej Fryderykowi II, królowi Prus w latach 1740-1786. Choć planów tych nigdy nie zrealizował, etos pruskiej sumienności odegrał znaczną rolę w wydanym kilka lat przed wojną opowiadaniu Śmierć $w$ Wenecji. Zgromadzone materiały wy-

bei Hamburg 1996, t. 1-2; H. Kurzke, Thomas Mann, das Leben als Kunstwerk, Frankfurt am Main 2001; S. Bruendel, Zwei Strategien intellektueller Einmischung: Heinrich und Thomas Mann im Ersten Weltkrieg, [w:] I. Gilcher-Holtey (hrsg.), Zwischen den Fronten: Positionskämpfe europäischer Intellektueller im 20. Jahrhundert, Berlin 2006, s. 87-116; K. Sontheimer, Thomas Mann und die Deutschen, München 1961; A. Kantorowicz, Heinrich und Thomas Mann, Berlin 1956.

${ }_{52}$ Zob. T. Mann, Gedanken im Kriege, [w:] tegoż, Aufsätze, Reden, Essays, Berlin 1983, t. 2, s. 11-29. 
korzystał raz jeszcze w eseju, do którego pisania przystąpił zaraz po ukończeniu Myśli czasu wojny. Esej nosi tytuł Fryderyk i wielka koalicja i powstawał między końcem września a połową grudnia 1914 roku. Jego celem było przeprowadzenie analogii między sytuacją Prus w latach wojny siedmioletniej i zajęciem neutralnej Saksonii a sytuacją Niemiec po wybuchu wojny światowej i zajęciem neutralnej Belgii. Zarówno Prusy Fryderyka II, jak i Niemcy Wilhelma II miały prawo do zajęcia tych państw, ponieważ tak naprawdę stały po stronie wrogów. Niespodziewany atak nie był niczym innym jak obroną konieczną. Jej zastosowanie było słuszne zarówno pod względem politycznym, jak i moralnym. Fryderyk II musiał wziąć na siebie winę niespodziewanego ataku, by uprzedzić działania przeciwników i im winę udowodnić. Zwycięstwo uprawomocniło jego poczynania. Rosja, Francja i Anglia są dziś sprzymierzone przeciw Niemcom, jak sto pięćdziesiąt lat wcześniej przeciw Prusom, ale także tym razem nie złamią Niemiec, najpotężniejszego państwa Europy53.

Esej ukazał się w styczniu i lutym 1915 roku w czasopiśmie „Neues Merkur". Został opublikowany raz jeszcze w czerwcu tego samego roku w postaci tomiku, zawierającego także Myśli czasu wojny i tak zwany List szwedzki - odpowiedź na ankietę dotyczącą szans na powojenne pojednanie - opublikowany nieco wcześniej w czasopiśmie „Svenska Dagbladet”54. W odpowiedzi tej Tomasz Mann rozważa problem odpowiedzialności za wybuch wojny i raz jeszcze porównuje sytuację Prus w roku 1756 do sytuacji Niemiec w roku 1914. Podkreśla występowanie w historii Niemiec dualizmu ducha i władzy. Niemiecka kultura wznosiła się najwyżej w warunkach braku państwa, w pierwszej połowie XIX wieku. Zjednoczenie Niemiec oznaczało kryzys tej kultury. Pora na syntezę kultury i władzy, czyli Trzecią Rzeszę. Będzie ona połączeniem duchowego dziedzictwa dążeń zjednoczeniowych lat 1813 i 1848 z politycznym realizmem Drugiej Rzeszy. Trzecia Rzesza to harmonijne połączenie władzy i kultury, polityki i sztuki 55 .

Listę wypowiedzi związanych z ówczesną postawą Tomasza Manna zamyka opublikowany w 1914 roku w monachijskim czasopiśmie „Zeit-

${ }^{53}$ Zob. T. Mann, Fryderyk i wielka koalicja, tłum. W. Kunicki, s. 71-126, [w:] tegoż, Moje czasy, Poznań 2002.

${ }_{54}$ Zob. tenże, An die Redaktion des „Svenska Dagbladet”, Stokholm, [w:] tegoż, Aufsätze, Reden, Essays..., s. 97-105.

55 Książkę zatytułowaną Trzecia Rzesza w roku 1923 wydał Arthur Moeller van den Bruck, jeden z najważniejszych przedstawicieli rozwijającego się w okresie międzywojennym ruchu intelektualnego, nazwanego rewolucją konserwatywną. Jego zwolennicy byli przekonani, że idee konserwatywne są bardziej postępowe, nowoczesne niż demokracja i liberalizm. Zob. A. Mohler, K. Weissmann, Die konservative Revolution in Deutschland 1918-1932, Graz 2005. 
-Echo" artykuł Dobre wieści z frontu, w którym autor raz jeszcze podkreśla podobieństwo między sztuką a wojną, artystą a żołnierzem (i odnosi je do siebie samego) ${ }^{56}$ oraz wydrukowany we „Frankfurter Zeitung” w sierpniu 1915 tekst zatytułowany Myśli dotyczace wojny, w którym mowa o moralnych cierpieniach Niemców, wystawionych na niezasłużoną nienawiść narodów Europy ${ }^{57}$.

W drugiej połowie października 1915 roku zaczęły powstawać Rozważania człowieka niepolitycznego. Rozprawą z bratem stały się z chwilą opublikowania $\mathrm{w}$ listopadowym numerze antywojennego czasopisma „Weiße Blätter” eseju Henryka poświęconego Emilowi Zoli. Tekst przedstawiał życie i twórczość francuskiego pisarza, jego negatywny stosunek do Napoleona III i proklamowanego w roku 1852 cesarstwa. W rzeczywistości była to zamaskowana krytyka cesarstwa niemieckiego. Napoleon III to Wilhelm II, wojna francusko-niemiecka z roku 1870 to wojna światowa, a Emil Zola i jego twórczość to Henryk Mann i jego powieści. Klęsce Francji i powstaniu Komuny Paryskiej odpowiada przyszła klęska cesarskich Niemiec i powstanie republiki. Upadek Napoleona III został proroczo zaplanowany na wiele lat przed jego spełnieniem jako zwieńczenie cyklu powieściowego o rodzinie Rougon-Macquartów. Dzieła Zoli są zapowiedzią społeczeństwa przyszłości, w którym zapanuje prawda, praca, nauka i demokracja. Republika jest ustrojem politycznym, w którym prawda nareszcie zajmie należne jej miejsce, a polityka utożsami się z człowieczeństwem. Zmiana ta jest nieunikniona, bo nie może przetrwać państwo zbudowane na przemocy, a nie na wolności i sprawiedliwości, państwo, które opiera się tylko na rozkazach i ślepym posłuszeństwie, w którym trzeba być albo wyzyskiwaczem, albo wyzyskiwanym. Prawdziwa władza jest nią wtedy, gdy opiera się na prawie, zakorzenionym w świadomości spełnionego obowiązku. Cesarstwo, które opiera swą władzę na sile, musi upaść. Zastąpi je republika, bo tylko ona podkreśla godność człowieka i otacza go szacunkiem. Polityka i literatura, zjednoczone w nierozerwalnym sojuszu, służą dobru i szczęściu rządzącej się sprawiedliwymi zasadami społeczności58.

Tomasz Mann dopatrzył się w eseju ataku na siebie, zwłaszcza w stwierdzeniu, że swoim estetycznym dystansem wobec rzeczywistości, powściągliwością w mówieniu prawdy o położeniu najbiedniejszych jest współodpowiedzialny za obecną sytuację Niemiec i czerpie z niej korzyści, podczas gdy zdolny do moralnego piętnowania społecznej niesprawiedli-

${ }_{56}$ Zob. T. Mann, Gute Feldpost, [w:] tegoż, Aufsätze, Reden, Essays..., s. 30-33.

${ }^{57}$ Zob. tenże, Gedanken zum Kriege [w:] tegoż, Aufsätze, Reden, Essays..., s. 106-109.

58 Zob. H. Mann, Zola, [w:] tegoż, Geist und Tat, Franzosen von 1780 bis 1930, Essays, Frankfurt am Main 1997, s. 119-203. 
wości Henryk musi milczeć. Starszy brat nie waha się sugerować, że postawa Tomasza to zdrada własnego narodu, że nawet teraz nie potrafi się do niej przyznać, obciążając się bardziej niż przywódcy polityczni, o których wiadomo, że czynią wszystko tylko ze względu na własne korzyści, podczas gdy pisarze powinni być sumieniem narodu.

Powstająca przez ponad dwa lata odpowiedź na esej brata ukazała się w ostatnich dniach października 1918 roku, równolegle z powieścią Poddany Henryka Manna, która ukończona jeszcze przed wojną i częściowo opublikowana w odcinkach, teraz dopiero mogła ukazać się w całości. Mimo wojennego wyczerpania i obniżenia poziomu życia w ciągu kilku miesięcy sprzedano sto tysięcy egzemplarzy powieści i tylko sześć tysięcy egzemplarzy Rozważań. Inne powieści Henryka osiągnęły łączny nakład około siedmiuset pięćdziesięciu tysięcy. Sytuacja ta jednak zmieniła się już w następnym roku. Zainteresowanie twórczością Henryka zaczęło słabnąć, rosły natomiast nakłady dzieł Tomasza. Pisarz odnalazł drogę porozumienia z elitami politycznymi republiki weimarskiej. Wyjątkową pozycję Tomasza Manna potwierdziła w roku 1929 roku literacka Nagroda Nobla. Z bratem, który ciężko zachorował, pogodził się na początku roku 1922. Henryk próbował już to uczynić w roku 1917. Wysłał pojednawczy list, który został odrzucony. Nigdy pisemnie Rozważań człowieka niepolitycznego nie skomentował. Do końca życia zapewniał, że ich nie przeczytał.

\section{Twórczość człowieka niepolitycznego}

Postawy Henryka i Tomasza Mannów odzwierciedlają podziały w społeczeństwie niemieckim początków XX wieku. Powieści i eseje Henryka Manna krytykują mentalność i sposób postępowania elity rządzącej, zarzucając jej nieuzasadnione poczucie wyższości, społeczny egoizm, dbałość wyłącznie o własne interesy. Wyrażają podstawowe żądania socjaldemokracji, dotyczące zbudowania sprawiedliwego państwa, gwarantującego równość wszystkich obywateli. Henryk Mann przez całe życie pozostał lewicowym intelektualistą. W roku 1950 władze Niemieckiej Republiki Demokratycznej zaproponowały mu stanowisko przewodniczącego utworzonej właśnie Akademii Sztuk. Pisarz propozycję przyjął, ale zmarł w trakcie przygotowań do wyjazdu ze Stanów Zjednoczonych.

Tomasz Mann natomiast usytuował się na prawicy, po stronie panujących. Odwoływał się do społeczeństwa stanowego, nadrzędnej roli monarchy i znaczenia protestantyzmu, z którego w wieku XIX uczyniono integrującą społeczeństwo religię narodową, nawiązując do tradycji jed- 
ności tronu $i$ ołtarza. Takie poglądy zbliżały go do konserwatystów, zarazem jednak akceptował formę rządów stworzoną przez Bismarcka, a tym samym podzielał stanowisko prawicowych liberałów. Ale światopogląd Tomasza Manna wykracza poza tradycyjny konserwatyzm. Pisarz poddał przeszłość romantycznej idealizacji, przeciwstawił współczesności dawną wspólnotę germańską opartą na związku z ziemią i określił jako różnicę między niemiecką kulturą a francuską cywilizacją. Z religii uczynił siłę irracjonalną i wywiódł z niej agresywną koncepcję jednostki, artysty, muzyki, sztuki, narodu i państwa. W jego poglądach widoczne są wpływy volkizmu, nurtu politycznego, który ukształtował się w drugiej połowie XIX wieku i zdobył duże znaczenie pod koniec pierwszej wojny światowej. Głosił on ideę niemieckiego narodu wybranego, widział w nim formę manifestacji metafizycznej, dążył do ożywienia germańskich wierzeń lub stworzenia niemieckiej wersji chrześcijaństwa, chciał państwa o silnie militarnej strukturze i dominującej pozycji w Europie, uzasadnionej hasłami darwinizmu społecznego, żądał przestrzeni życiowej na Wschodzie i asymilacji lub wygnania Żydów. Wprawdzie Tomasz Mann przewagę Niemców motywował nie rasowo, lecz kulturowo, ale posłużył się myślami antysemity Paula de Lagarde, filozofa i historyka kultury, który traktował liberalizm jako obcy niemieckiej naturze i który po raz pierwszy zaproponował wysłanie Żydów na Madagaskar. Pod jego, a także Juliusa Langbehna, autora przywoływanej w Rozważaniach książki Rembrandt jako wychowawca, wpływem wykorzystał religię i sztukę jako narzędzia do zwalczania demokracji, podporządkował je nacjonalizmowi i zaakceptował przemoc. Jej sakralizacja posłużyła uzasadnieniu wojny $\mathrm{z}$ ateistycznym Zachodem. Dokonana w Rozważaniach relatywizacja wartości oznaczała przejście od dziewiętnastowiecznego konserwatyzmu państwowego do skrajnie prawicowych poglądów ugrupowań powojennych, które już wkrótce przeciwstawią się republice weimarskiej.

Irracjonalizm, pochwała wojny, odwołania do autorów propagujących rasizm i poglądów uznających wyższość Niemców nad innymi narodami naraziły pisarza w późniejszych latach na zarzut, że swoim esejem przecierał drogę ideologii nazistowskiej:

„Rozważania człowieka niepolitycznego” od pierwszego do ostatniego wiersza były dokumentem surowej i gniewnej powagi, produktem intelektualnych i moralnych konwulsji, które czasami doprowadzały autora na skraj mentalnego zawału. Były i są Białą, a raczej Czarną Księgą resentymentu, który toczył dusze tak wielu Niemców. Dla Tomasza Manna miały stanowić rozliczenie, choć bardzo długo trwało, nim uwolnił się zupełnie od przedstawień nienawiści i wrogości. Były jednocześnie wyrazem konserwatywnego protestu, który długo jeszcze okupował duszę niemiecko-narodowego mieszczaństwa - także jego własną. 
Ich najgłębszą treścią, pomimo wielu świetnych fragmentów, była zapowiedź rewolty irracjonalizmu, która miała wtrącić w przepaść Niemcy, a z nimi - całą Europę 5 .

Tomasz Mann w przepaść wtrącić się nie dał dzięki koncepcji ironii i przekonaniu, że zwalczanie demokracji jest formą jej popierania. Tym paradoksalnym stwierdzeniem rozerwał krąg nagromadzonych sprzeczności, uwolnił się od moralnego relatywizmu, pogodził z bratem i teraźniejszością. Pisarz nie traktował państwa jako celu samego w sobie. Widział w nim środek zapewniający odpowiednie warunki do twórczej pracy. Gdy okazało się, że warunki te stwarza nie tylko państwo zwierzchnie, ale także demokratyczne, że ono też pozwala rozwijać jego artystyczne koncepcje, oddał mu się do dyspozycji. Przyszło mu to tym łatwiej, że władze republiki zabiegały o jego przychylność, zapraszały do uświetniania różnych oficjalnych uroczystości. Okazję do ostatecznego opowiedzenia się po stronie demokracji przyniosły obchodzone w roku 1922 roku sześćdziesiąte urodziny Gerharda Hauptmanna. Tomasz Mann wygłosił wtedy w Berlinie mowę zatytułowaną $O$ niemieckiej republice ${ }^{60}$, która przypieczętowała nowy sojusz ${ }^{61}$.

Postawa artystycznej ironii, uzupełniających się przeciwieństw i idea środka wieńczyły ewolucję rozpoczętą długo przed wybuchem wojny w opowiadaniu Tonio Kröger, które zawiera pierwsze sformułowanie zasady ironii, i powieści Królewska wysokość, kończącej się przymierzem między monarchią a demokracją, a także miłością zrodzoną między ich przedstawicielami. Obydwa utwory są kilkakrotnie przywoływane i cytowane w Rozważaniach. W dziele tym zbiegają się wszystkie dotychczasowe zagadnienia twórczości Manna. Poddane zewnętrznej presji polityki i wewnętrznej kryzysu twórczego, wywołanego pesymizmem kulturowym, skumulowały się w metodzie, umożliwiającej opis i interpretację świata w późniejszych powieściach. Konflikt z bratem i atak na demokrację oznaczały obronę prawa do odmienności i proces poznawania siebie. Ponieważ starszy brat skupił się na racjonalnej stronie ludzkiej natury, młodszemu pozostała ta część, nad którą ani rozum, ani brat władzy mieć nie mogli. Uznał, że tylko $\mathrm{w}$ ten sposób może podkreślić swoją twórczą niezależność. Dlatego odrzucił kojarzony z Francją światopogląd Henryka i wybrał irracjonalizm, który jego poglądom nadał skrajnie prawicowy charakter. Ale ujawnienie moralnych i politycznych konsekwencji takiego

${ }^{59}$ K. Harpprecht, dz. cyt., s. 429.

60 Zob. T. Mann, O niemieckiej republice, [w:] tegoż, Moje czasy..., s. 127-168.

61 Zob. J. Kępa, Od świętej przemocy do świętej demokracji-przemiany światopogladu Tomasza Manna w latach 1914-1922, [w:] Od Christianitas do Unii Europejskiej, red. Ł. Święcicki, A. Wielomęski, Warszawa 2015, s. 173-204. 
stanowiska samo w sobie oznaczało już przełom i zmianę, co podkreśla motto całego eseju ${ }^{62}$. Konflikt, choć przysporzył wielu zwątpień i udręk, uwolnił Tomasza od określania siebie poprzez negację poglądów brata, stał się wstępem do odkrycia własnego powołania pisarskiego, sformułowania niezależnego, pozytywnego stanowiska i uodpornił na pokusy, którym niebawem zaczął ulegać naród. Twórca bardzo wcześnie, bo już latem 1921 roku, odnotował powstanie ruchu nazistowskiego i określił go mianem „ekscesów ze swastyką"63. W 1925 roku stworzył jego trafną charakterystykę:

„Nie traćmy zbyt wielu słów na opis niemieckiego faszyzmu i jego w pełni wytłumaczalne pochodzenie. Wystarczy stwierdzenie, że jest on religią etniczną, która kategorycznie neguje nie tylko międzynarodowe środowiska żydowskie, lecz wyraźnie także chrześcijaństwo jako uczłowieczoną potęgę, i której kapłani nie mniej nieprzyjaźnie odnoszą się do humanizmu naszej literatury klasycznej. Jest on narodowym pogaństwem, kultem Wotana - wyrażając się nieprzyjaźnie (a chcemy nieprzyjaźnie się wyrazić) - romantycznym barbarzyństwem"64.

Po dojściu Hitlera do władzy musiał Mann Niemcy opuścić. Ponieważ popierał demokrację przez jej zwalczanie, nie widział konieczności tłumaczenia się ze swoich poglądów z okresu pierwszej wojny światowej, a tym bardziej ich odwoływania. Dopiero głęboka potrzeba samousprawiedliwienia w obliczu ogromu zbrodni nazistowskich podyktowała mu Doktora Faustusa - powieść, w której raz jeszcze powraca zagadnienie światopoglądowych różnic między Niemcami a Zachodem jako przyczyny konfliktu zbrojnego. Zawiera ona przekonanie, że nazizm to efekt niemieckiego protestu przeciw nowoczesności, wyrażony w dążeniu do wskrzeszenia średniowiecza. Jej bohaterowie bronią przeszłości tak jak niegdyś czynił to człowiek niepolityczny; sięgają do germańskich mitów i zmieniają religię w siłę irracjonalną, czyniąc z niej narzędzie polityczne, uzasadniające bunt przeciw rozumowi, relatywizację zasad moralnych, niszczenie zachodniego porządku społecznego i gloryfikację opartego na przemocy państwa. W losach uosabiającego niemiecką mentalność Adriana Leverkühna znajdujemy artystycznie przetworzone główne wątki Rozważań. Takim zabiegiem pisarz potwierdził niebezpieczną bliskość swoich dawnych poglądów z hasłami nazistowskimi:

62 Pogódź się z sobą! Poznaj, czym jesteś! Cytat pochodzi ze sztuki Johanna Wolfganga Goethego Torquato Tasso. Drugie motto to równie znamienny cytat z przetłumaczonej przez Tadeusza Boya-Żeleńskiego sztuki Moliera Szelmostwa Skapena: Po kiegóż diabła tazit na ten statek?

${ }^{63}$ H. Kurzke, dz. cyt., s. 286.

${ }^{64}$ K. Harpprecht, dz. cyt., s. 497. Harpprecht przytacza tu słowa Tomasza Manna. 
W rozwoju Niemiec od czasów romantyzmu dostrzegł fatum, które miało decydujący wpływ na współczesność. Ujrzał podobieństwo między historią niemieckiej myśli a duchową postawą Hitlera - podobieństwo, które wyraźnie odniósł także do własnego rozwoju intelektualnego ${ }^{65}$.

Podobieństwo to podkreślił $\mathrm{w}$ wygłoszonym wkrótce po zakończeniu wojny eseju rozrachunkowym, zatytułowanym Niemcy $i$ naród niemiecki66.

Uwolniona od polityki, irracjonalizmu i wojny twórczość Tomasza Manna stała się realizacją nakreślonego w zakończeniu Rozważań dążenia do światopoglądowego kompromisu. W późniejszych powieściach żyje duch pojednania z bratem, uogólniony do szukania porozumienia między Boskim a ludzkim pochodzeniem porządku społecznego. Twórczość braci Mannów odzwierciedla konflikt stanowego, hierarchicznego porządku społecznego, opartego na wartościach konserwatywnych z oświeceniowymi założeniami umowy społecznej, gospodarczego liberalizmu i demokracji. Konflikt ten dochodzi do głosu już w Buddenbrookach. Wychowany $\mathrm{w}$ tradycji protestanckiej Tomasz Buddenbrook daremnie przeciwstawia się bezwzględnym zasadom zwycięskiego kapitalizmu, a jego utalentowany muzycznie syn świadomie wybiera chorobę i śmierć, przeczuwając, że nie potrafi odnaleźć się w nowej, bismarckowskiej rzeczywistości. Zderzenie tradycji i nowoczesności w Czarodziejskiej górze zostaje ukazane już nie w historii niemieckiej rodziny mieszczańskiej, lecz w losach europejskiej rodziny narodów. Hans Castorp musi wybierać między religijną żarliwością Naphty a demokratycznym wolnomyślicielstwem Settembriniego, pogodzonych tylko na chwilę w wizji, jaką główny bohater przeżywa w czasie śnieżnej zamieci. Dopiero ukochany syn biblijnego patriarchy w tetralogii Józef $i$ jego bracia osiąga syntezę duchowości i polityki, świętości i świeckości, wiary i rozumu. W tej powieści Tomasz Mann stał się człowiekiem prawdziwie niepolitycznym, to znaczy takim, który relacje z ludźmi buduje na relacji z Bogiem, czyniąc z niej fundament moralności i racjonalnego obrazu świata. Powieść jest przeniesionym w świat starożytności przekonaniem, że zaspokajającą potrzebę sensu życia jedność sacrum i profanum odnaleźć można także w zdominowanym przez demokrację społeczeństwie współczesnym ${ }^{67}$. Opisany w powieściach Manna konflikt światopoglądowy nadal jednak istnieje. Jest częścią naszej świadomości. Można go dostrzec w podstawowych aktach prawnych Unii Eu-

${ }^{65}$ H. Wißkirchen, Die Familie Mann, Reinbek bei Hamburg 1999, s. 112-113.

${ }_{66}$ Zob. T. Mann, Niemcy i naród niemiecki, tłum. W. Kunicki, [w:] T. Mann, Moje czasy..., s. 388-408.

67 Zob. J. Kępa, Sacrum i profanum w twórczości Tomasza Manna, Wrocław 2008, skrót: „Pro Fide, Rege et Lege” 2015, nr 1 (73-74), s. 297-325. 
ropejskiej. Mówią one o duchowym, religijnym dziedzictwie przeszłości, uznają wartości absolutne, uniwersalne, którym człowiek zawdzięcza swą godność, a zarazem relatywizują je do warunków kulturowych i pozostawiają ich interpretację poszczególnym państwom członkowskim ${ }^{68}$. W zasadzie ironii, uzupełniających się przeciwieństw i teorii środka dostrzec więc należy wysiłek zachowania ciągłości światopoglądowej Europy $\mathrm{w}$ trwających od stuleci przemianach gospodarczych, politycznych i naukowych. Dziś, w erze postindustrialnej, postawa ta opisuje różnice między przeszłością a teraźniejszością jeszcze trafniej niż sto lat temu, a twórczość Tomasza Manna ostrzega przed buntującą się przeciw nowoczesności wola mocy, ale przede wszystkim przed rezygnacją z mądrości, jaką niesie przeszłość.

\section{LITERATURA}

Bruendel S., Zwei Strategien intellektueller Einmischung: Heinrich und Thomas Mann im Ersten Weltkrieg, [w:] I. Gilcher-Holtey (hrsg.), Zwischen den Fronten: Positionskämpfe europäischer Intellektueller im 20. Jahrhundert, Berlin 2006, s. 87-116.

Giertych M., Elastyczna aksjologia Unii Europejskiej, „Więź”, 2012 nr 1, s. 45-60.

Harrprecht K., Thomas Mann, eine Biographie, Reinbeck bei Hamburg 1996, t. 1-2. Kantorowicz A., Heinrich und Thomas Mann, Berlin 1956.

Kępa J., Od świętej przemocy do świętej demokracji - przemiany światopogladu Tomasza Manna w latach 1914-1922, [w:] Od Christianitas do Unii Europejskiej, red. Ł. Święcicki, A. Wielomęski, Warszawa 2015.

Kępa J., Sacrum i profanum w twórczości Tomasza Manna, Wrocław 2008.

Koopmann H., Thomas Mann - Heinrich Mann: Die ungleichen Brüder, München 2005.

Kurzke H., Thomas Mann, das Leben als Kunstwerk, Frankfurt am Main 2001.

Mann H., Geist und Tat, Franzosen von 1780 bis 1930, Essays, Frankfurt am Main 1997.

Mann T., Aufsätze, Reden, Essays, Berlin 1983.

Mann T., Betrachtungen eines Unpolitischen, Frankfurt am Main 2001.

Mann T., Moje czasy, Poznań 2002.

Mendelssohn P. de, Der Zauberer. Das Leben des deutschen Schriftstellers Thomas Mann, t. 1-3, Frankfurt am Main 1996.

Mohler A., Weissmann K., Die konservative Revolution in Deutschland 1918-1932, Graz 2005.

Sontheimer K., Thomas Mann und die Deutschen, München 1961.

Wißkirchen H., Die Familie Mann, Reinbek bei Hamburg 1999.

${ }^{68}$ Zob. M. Giertych, Elastyczna aksjologia Unii Europejskiej, „Więż”, 2012 nr 1, s. 45-60. 
